Meta

Journal des traducteurs

Translators' Journal

\title{
Assessing Apparently Equivalent Translations in the News Media
}

\section{Kyle Conway}

Volume 50, numéro 4, décembre 2005

Pour une traductologie proactive - Actes

For a Proactive Translatology - Proceedings

Por una traductología proactiva - Actas

URI : https://id.erudit.org/iderudit/019834ar

DOI : https://doi.org/10.7202/019834ar

Aller au sommaire du numéro

Éditeur(s)

Les Presses de l'Université de Montréal

ISSN

0026-0452 (imprimé)

1492-1421 (numérique)

Découvrir la revue

Citer cet article

Conway, K. (2005). Assessing Apparently Equivalent Translations in the News Media. Meta, 50(4). https://doi.org/10.7202/019834ar
Résumé de l'article

Cet essai représente une tentative préliminaire de formuler une approche pour examiner des mots et leurs traductions qui sont employés dans les médias journalistiques et qui, selon toute apparence, sont équivalents. En prenant comme point de départ l'essai sur la tâche du traducteur de Walter Benjamin et en se servant de la phénoménologie d'Edmund Husserl et de la linguistique énonciative d'Antoine Culioli et de Paul Laurendeau, l'auteur soutient que cette équivalence apparente est trompeuse, et ce pour au moins deux raisons : d'abord parce que des présuppositions culturelles différentes sous-tendent l'interprétation de ces mots et de leurs traductions; ensuite au fur et à mesure que les implications de ces mots et de leurs traductions sont transmises et contestées (par des acteurs politiques, des reporters, des équipes de rédaction), leurs sens sont en fait transformés.
Ce document est protégé par la loi sur le droit d'auteur. L'utilisation des services d’Érudit (y compris la reproduction) est assujettie à sa politique d'utilisation que vous pouvez consulter en ligne.

https://apropos.erudit.org/fr/usagers/politique-dutilisation/ 


\title{
Assessing Apparently Equivalent Translations in the News Media
}

\author{
KYLE CONWAY \\ University of Wisconsin-Madison, Madison, USA \\ krconway@wisc.edu
}

\begin{abstract}
RÉSUMÉ
Cet essai représente une tentative préliminaire de formuler une approche pour examiner des mots et leurs traductions qui sont employés dans les médias journalistiques et qui, selon toute apparence, sont équivalents. En prenant comme point de départ l'essai sur la tâche du traducteur de Walter Benjamin et en se servant de la phénoménologie d'Edmund Husserl et de la linguistique énonciative d'Antoine Culioli et de Paul Laurendeau, l'auteur soutient que cette équivalence apparente est trompeuse, et ce pour au moins deux raisons : d'abord parce que des présuppositions culturelles différentes sous-tendent l'interprétation de ces mots et de leurs traductions; ensuite au fur et à mesure que les implications de ces mots et de leurs traductions sont transmises et contestées (par des acteurs politiques, des reporters, des équipes de rédaction), leurs sens sont en fait transformés.
\end{abstract}

\begin{abstract}
This essay represents a preliminary attempt to devise a method for examining words and their apparently equivalent translations as they appear in the news media. Taking Walter Benjamin's essay on the task of the translator as a starting point and drawing on Edmund Husserl's phenomenology and Antoine Culioli's and Paul Laurendeau's enunciative linguistics, the author argues that this appearance of equivalence is deceptive, for at least two reasons: first, because differing, culturally specific assumptions underlie the interpretations of these words and their translations; and second, because as the implications of these words and their translations are reported upon and contested (by political actors, by reporters, by editorialists), their meanings effectively change.
\end{abstract}

\section{MOTS-CLÉS/KEYWORDS}

news media, translator's task, phenomenology, enunciative linguistics

\section{Introduction: Translation and the Journalist's Task}

In his productively enigmatic essay on the task of the translator, Walter Benjamin (1997: 156-157) makes the following assertion, which I believe should be of particular interest to journalists:

[I]t is necessary to distinguish, within intention, the intended object from the mode of its intention. In "Brot" and "pain," the intended object is the same, but the mode of intention differs. It is because of their modes of intention that the two words signify something different to a German or a Frenchman, that they are not regarded as interchangeable, and in fact ultimately seek to exclude one another [...].

What he means by this, according to Paul de Man (1986), who reads this section of Benjamin's essay through the lens of Edmund Husserl's phenomenology, is that when speakers designate something by linguistic means (or, in a larger sense, when they "intend" something by directing their attention toward it), they do so within a conceptual horizon that is shaped to a large degree by the language they speak. Within the bounds of this horizon, the word they choose evokes certain associations, while others are excluded. These associations and exclusions work to shape the word's "mode of intention" - i.e., how it points to or "intends" its referent. In de Man's (1986: 87) illustration, 
To mean "bread," when I need to name bread, I have the word Brot, so that the way in which I mean is by using the word Brot. The translation will reveal a fundamental discrepancy between the intent to name Brot and the word Brot in its materiality, as a device of meaning. If you hear Brot in this context of Hölderlin, who is so often mentioned in [Benjamin's] text, I hear Brot und Wein necessarily, which is the great Hölderlin text that is very much present in this - which in French becomes Pain et vin. "Pain et vin" is what you get for free in a restaurant, in a cheap restaurant where it is still included, so pain et vin has very different connotations from Brot und Wein. It brings to mind the pain français, baguette, ficelle, battard, all those things $[\ldots]$.

Why should this interest journalists in particular? Their concern here is entirely practical: whether reporting on minority language groups within a domestic context (such as Hispanics in the United States) (Anders 2000) or on events taking place in a foreign context (such as the Iraq war as covered by US news media) (Beckerman 2004), journalists must draw upon their knowledge (or their translator's knowledge) of the language and culture of those they interview in order to make their story make sense for their readers, listeners, or viewers. To be effective, they must be aware of the different connotations words and their translations have, or, again in a larger sense, they must be aware of how words and their translations "intend" their referents differently for different cultures.

Despite the apparent centrality of this concern, however, only limited scholarly work (e.g., Abdel-Hafiz 2002; Al-Amri 2002; Bjørge 2003; Wilke and Rosenberger 1994) has been done to address questions such as: what role does translation play in the process of gathering the news? What role does it play in the process of writing news stories? Journalists themselves have addressed related questions, albeit indirectly; those who report across cultural and linguistic lines are typically well aware of not only the limited capacity of one language to convey another but also the social constraints reporters face as they work to gain the trust of those they write about while maintaining the trust of their readers (see Anders 1999, 2000; Beckerman 2004). But important scholarly questions still remain, including: how can we describe and eventually evaluate translations of apparently equivalent words by taking into account their modes of intention?

This is the question I begin to address in this paper. To do this, I draw on Husserl's (1970) discussion in The Crisis of European Sciences and Transcendental Phenomenology of the relation of intention and modes of intention to a speaker's and community's conceptual horizon. I recast Husserl's observations within a more explicitly linguistic framework by reinterpreting them through the lens of Antoine Culioli's $(1981,1995)$ concept of "notion" and Paul Laurendeau's (1997) discussion of the "deformability" of notions in discourse. I am concerned in particular to examine politically charged words, employed in ongoing reportage (rather than one-time stories), whose translations seem to represent apparent semantic equivalents ${ }^{1}$. My point is to demonstrate that this appearance of equivalence is deceptive, for at least two reasons: first, as Benjamin suggests, because differing, culturally specific assumptions underlie the interpretations of these words and their translations; and second, because as the implications of these words and their translations are reported upon and contested (by political actors, by reporters, by editorialists), their meanings - and their modes of intention - effectively change. I conclude with a number of observations on methodological implications for scholars studying translation in the news media.

\section{Horizon and Intentionality}

"Intention in Husserl," writes de Man (1986: 94), as "in phenomenology as it establishes itself as a serious philosophical discipline," is "primarily a critique of the notion of the subject as simply the expression of its own wishfulness." This critique grows out of Husserl's conclusion that people come to know the world within the bounds of a conceptual horizon that is not entirely of their own making, a conclusion he arrives at by questioning how a person, having encountered a thing, comes to conceive it as the thing it is perceived to be (or, less tautologically, how a person comes to recognize a thing as others would recognize it by sharing the cultural conventions that make the thing meaningful). He argues that two dialectically linked phenomena are at play. On one hand, the person examines the thing, touches it, sees it, finally arriving at a synthesis of these 
sensations, retaining them even when they have stopped being actual sensations. This synthesis makes it possible to " "get to know' the thing" (Husserl 1970: 158). On the other hand, the person is constrained even upon first seeing the thing by the thing's horizon:

Even if I stop at perception, I still have the full consciousness of the thing, just as I already have it at the first glance when I see it as this thing. In seeing I always "mean" it with all the sides which are in no way given to me, not even in the form of intuitive, anticipatory presentifications. Thus every perception has, "for consciousness," a horizon belonging to its object (i.e., whatever is meant in the perception). (Husserl 1970: 158)

As the person continues to examine the thing from different perspectives, new sensations lead to an "alteration in validity" (Husserl 1970: 161), which in turn affects the synthesis as it continues to develop within the limits imposed by the thing's horizon, resulting in "an advancing enrichment of meaning and a continuing development of meaning" such that "everything is taken up into the unity of validity or into the one, the thing" (Husserl 1970: 158).

People, however, are fundamentally social, and the community in which a person lives influences the synthesis he or she arrives at:

[I]n living with one another each one can take part in the life of the others. Thus in general the world exists not only for isolated men but for the community of men; and this is due to the fact that even what is straightforwardly perceptual is communalized.

In this communalization, too, there constantly occurs an alteration of validity through reciprocal correction. In reciprocal understanding, my experiences and experiential acquisitions enter into contact with those of others, similar to the contact between individual series of experiences within my (one's own) experiential life [...]. (Husserl, 1970: 163)

Thus the thing as we come to know it is intersubjectively constituted. Subjective perception is held in check by the perception of others, and the individual's conceptual horizon, comprising the set of "valid" conceptions of things in the world (to which the modes of intention within the horizon correspond), is held in constant dialectical tension with that of the community.

While Husserl's analysis of "alterations of validity" is above all "kinesthetic" (Husserl 1970: 161), I want to expand his analysis here by considering an analogous process of "alteration of validity" that occurs through language ${ }^{2}$. Culioli provides a fundamental tool for this examination in his concept of "notion," a flexible term (Culioli 1995: 33) that he describes as "une forme organisatrice, génératrice de relations prédicatives" [an organizing form capable of generating predicative relations] or as "un ensemble que l'on peut exprimer, par exemple, par ,lire; lecture; livre; lecteur; bibliothèque; etc." [c'est-à-dire] qu'on ne peut pas ramener les choses à une unité lexicale" [a set that one can express such as "to read, reading, book, reader, library, etc.," which is to say that it cannot be reduced to a lexical unit] (Culioli 1981: 64, 68) ${ }^{3}$.

In his essay De la « déformabilité » des notions en discours, Laurendeau (1997) extends Culioli's analysis of the concept of notion by describing how the dialectic of notional schematization and deformation operates around words acting as lexical captors. By "schematization" he means "l'élaboration, par le moyen d'une langue, d'un micro-univers que A présente à $B$ dans l'intention d'obtenir un certain effet sur lui" [the elaboration, by linguistic means, of a micro-universe that A presents to B in hopes of having a certain effect on him] (JeanBlaise Grize, qtd. in Laurendeau 1997: 44, n. 2). Schematization functions by stabilizing " $u n$ contenu notionnel en polarisant autour d'un certain nombre de capteurs lexicaux celles de leurs acceptions retenues aux fins du développement [discursif] en cours" [notional content by polarizing around a certain number of lexical captors those of their meanings that are mobilized by a speaker to support the ongoing discursive development] (Laurendeau 1997: 30). Two factors influence the schematization that occurs in a discourse, factors that I contend are analogous to intention and horizon as described by Husserl: "le sens lexical est engagé dans une organisation référentielle double. De fait, cette organisation référentielle est à la fois ,,initiale” (eu égard au discours spécifique se constituant) et „démarquée” (eu égard aux référents autant qu'à la doxa 
intersubjective)" [lexical meaning is engaged in a doubly referential organization. In fact, this referential organization is at once initial (considering the specific discourse being constituted) and received (considering the referents as well as the intersubjective doxa)] (Laurendeau 1997: 33). Thus the first speaker, by initially directing the second speaker's attention to select elements within their discursive universe, elaborates a "micro-universe" within the received horizon of the intersubjective doxa (i.e., within the system of shared constraints imposed by taken-for-granted assumptions that shape how the two speakers make sense of the world).

But this "micro-universe" does not remain static; instead, it undergoes a process of deformation. Over the course of actually occurring discourse (discours effectif), speakers enrich the initially schematized notional domains by repeatedly employing words that are constitutive of those domains. As they argue with each other, agree with each other, and generally expound on the topic in question, they each invest those notions with meanings that had not been there previously for their interlocutor. This results in a new schematization that, given such discourse's fundamentally dialogical nature, remains always open-ended and subject to further deformation. For the speakers in question, this new schematization represents a new set of elements within their discursive universe which they are constrained to take into account and respond to. In other words, it represents a subtly changed mutual horizon.

Conceiving words as lexical captors around which notional content is polarized promises to be a productive approach for considering the modes of intention of words used in ongoing journalistic discourse. If we recognize that the mode of intention of a word functioning as a lexical captor corresponds to the "valid" (i.e., intersubjectively arrived at) conception of the notion within the conceptual horizon of the community in question, then understanding the schematization/deformation dialectic operating within actually occurring discourse allows us to recognize that this conceptual horizon (and the resulting modes of intention of the words within it) is constantly - if incrementally - evolving.

This (for the time being preliminary) conclusion suggests a number of important questions regarding journalists' translations of politically charged words. Such words and their translations are linked in a complex relationship of both dependence and independence: dependence, first, because one is a translation of the other (or, more accurately in some circumstances, they are translations of each other); and independence, second, because both the word and its translation have evolved within different conceptual horizons. More important, they continue to evolve (and, at the same time, the horizons to which their modes of intention are dialectically linked continue to evolve) as journalists and political actors engage in a larger ideological struggle to give definition to the words in question ${ }^{4}$. It is thus important to ask in what social and historical context this evolution takes place. What effect does the journalistic tradition out of which the news organization has grown have on how a word is deployed? What is the social (and possibly political) role of the person employing the word? What are the effects of that person's authority (or lack thereof) on how other people respond to his or her use of the word ${ }^{5}$ ?

\section{Conclusion: Toward a Dialogic Understanding of Translation}

While the theoretical sketch I have laid out above offers - I hope - a new way to go about asking questions concerning the translations of words in the news media, its more fundamental insight that words "accumulate" meaning through use and reuse, acquiring what Ginette Michaud (1998) has evocatively called "la mémoire des mots" [word memory] - is by no means new. Many theorists from varying disciplines have observed this phenomenon and proposed approaches to understanding it; by way of concluding this paper, I would like to draw on one of the approaches I find most productive, namely that of Mikhail Bakhtin's dialogism. Specifically, I want, first, to briefly consider Bakhtin's understanding of an utterance's "mode of intention" and, second, to point to methodological implications for scholars studying translation in the news media that derive from certain conclusions Bakhtin reaches. 
In an essay he wrote in the mid-1930s, Bakhtin (1981: 276) postulates that:

[...] any concrete discourse (utterance) finds the object at which it was directed already as it were overlain with qualifications, open to dispute, charged with value, already enveloped in an obscuring mist-or, on the contrary, by the "light" of alien words that have already been spoken about it. It is entangled, shot through with shared thoughts, points of view, alien value judgments and accents. The word, directed toward its object, enters a dialogically agitated and tension-filled environment of alien words, value judgments and accents, weaves in and out of complex interrelationships, merges with some, recoils from others, intersects with yet a third group: and all this may crucially shape discourse, may leave a trace in all its semantic layers, may complicate its expression and influence its entire stylistic profile.

How does one go about describing a word's trajectory? Or, to ask a more complicated question, how does the trajectory itself - with its weaving in and out of complex relationships as the word merges with, recoils from, and intersects with other words - shape the task of its own description? To describe how a word and its translation are employed by journalists in different cultural contexts is to perform an act of exegesis and, by that, an act of interpretation or hermeneutics. In a larger sense, then, it is to perform an act of translation, albeit at a certain degree of remove (cf. Steiner 1998). Scholars, however, are no less constrained than journalists by the conceptual horizons within which they must work, and any apparent equivalence between a journalist's story and a scholar's "translation" of it - manifest in certain claims a scholar might make about the verisimilitude of her or his analysis - is problematic for all the reasons enumerated above.

Bakhtin was aware of this paradox. His response is as follows:

The first task is to understand the work as the author himself understood it, without exceeding the limits of his understanding. This is a very difficult problem and usually requires introducing an immense amount of material.

The second task is to take advantage of one's own position of temporal and cultural outsideness. Inclusion in our (other's for the author) context.

The first stage is understanding [...]; the second stage is scholarly study [...]. (Bakhtin 1986: 144-145)

Thus for Bakhtin, this paradox - that I cannot escape the constraints imposed by a system of things taken for granted that I seek as a scholar to make explicit-is "never a matter for despair" (Emerson 1983: 25). Rather, it suggests that my task as a scholar is not to establish some sort of equivalence between a news media text and my analysis of it but to make a critical intervention from a position of "participative outsideness" (de Michiel 1999: 693): "We raise new questions for a foreign culture, ones that it did not raise itself: we seek answers to our own questions in it; and the foreign culture responds to us by revealing to us new aspects and new semantic depths" (Bakhtin, qtd. in de Michiel 1999: 693).

\section{NOTES}

1. An example: in 1987, as part of the Meech Lake Accord, Québec agreed to accept the patriation of the Canadian constitution from London on the condition that the predominately French-speaking province be recognized as a "société distincte," or, in English, as a "distinct society." To all appearances, "société distincte" and "distinct society" were semantic equivalents; their equivalence was even given institutional authority by the Canadian and Québécois governments, which recognized the English and French versions of the accord's "distinct society" clause as carrying the same juridical weight. However, as I have demonstrated elsewhere (Conway 2002-2003), the understandings of what each term implied were radically different in Ontario and Québec, as news coverage of reactions evoked by the terms made clear.

2. I break with Husserl at his point in that Husserl places what seems to me to be an inordinate emphasis on the unity and harmony of the intersubjectively arrived at experience of the thing. This translates, in his discussion of language in the essay on the origin of geometry (Husserl 1970: 353-378), into a conception of words as stable and 
self-identical (see also Fisette 2000). In journalistic discourse, as I hope to demonstrate, perceptions of things or events whose meanings are politically charged are hardly stable, unitary, or harmonious.

3. All bracketed glosses from the French are my own.

4. Jacob Levenson (2004), for instance, presents a compelling description of this struggle as it implicates both politicians and journalists in his discussion of the meaning and evolution of the notion of the "war on terror." Seeking to understand how the press came to use a fundamentally ambiguous term, he traces the genealogy of the trope of war as US politicians have used it to describe political reactions to social crises.

5. I want to emphasize the centrality of these questions. To give an example of their importance: as Edward Said (2000) demonstrates in his examination of US media coverage of the Middle East and Islam during the Iran hostage crisis in 1979, official foreign policy exercises a great deal of influence over the way news organizations cover certain stories. Journalists at this time, often drawing on academics with little direct knowledge of Islam, wrote stories that followed the discourse of modernization informing US approaches to the so-called Third World in the 1970s. While this discourse "had acquired an almost unquestioned social, and certainly cultural, authority in the United States," it in no way reflected popular sentiment in the countries where it was applied (Said 2000: 191). Said does not explicitly address questions of translation here, but I am convinced that close examination of news texts produced during this time would reveal politically charged words and their translations as sites for ideological struggle. Mohammed el-Nawawy and Adel Iskandar's (2003) examination of the Arab-language news network AlJazeera-a more recent example of US-Arab news reporting, this time from an Arab perspective-would seem to confirm this when the authors make observations such as, "Critics have [...] accused Al-Jazeera of having a proPalestinian slant because its correspondents call Palestinian suicide-bombers shuhada (martyrs), not terrorists" (elNawawy and Iskandar 2003: 207).

\section{REFERENCES}

ABDEL-HAFIZ, A.-S. (2002): "Translating English Journalistic Texts into Arabic: Examples from the Arabic Version of Newsweek", International Journal of Translation 14-1, p. 79-103.

AL-AMRI, W. (2002): "Semiotics, Translation and the Press", doctoral dissertation, University of Manchester Institute of Science and Technology.

ANDERS, G. (1999): "The Crucible", American Journalism Review, p. 22-31.

ANDERS, G. (2000): “Talking the Talk”, American Journalism Review 53, p. 30-36.

BAKHTIN, M.M. (1981): "Discourse in the Novel”, in Holquist, M. (ed.): The Dialogic Imagination, translated by EMERSON, C. and M. HolQuist, Austin, University of Texas Press, p. 259-422.

BAKHTIN, M.M. (1986): "From Notes Made in 1970-71", in EMERSON, C. and M. HolquisT (eds.): Speech Genres and Other Late Essays, translated by McGeE, V. W., Austin, University of Texas Press, p. 132-158.

BECKERMAN, G. (2004): "In Their Skin”, Columbia Journalism Review, p. 40-43.

BENJAMIN, W. (1997): “The Translator's Task”, translated by RENDALL, S., TTR: traduction, terminologie, rédaction 10-2, p. 151-165.

BJøRGE, A. K. (2003): “The Explicitation of Proper Names in Expository News Texts”, International Journal of Applied Linguistics 13-1, p. 115-138.

Conway, K. (2002-2003): «Les Interprétations multiples de société distincte lors de l'accord Meech: une lecture du Toronto Star et de La Presse de Montréal », Journal of Canadian Studies 37-4, p. 112-130.

Culioli, A. (1981): «Sur le concept de notion », Bulletin de linguistique générale et appliquée 8, p. 62-79.

Culioli, A. (1995): Cognition and Representation in Linguistic Theory, in LidDLE, M. (ed.): translated by StonhaM, J., Philadelphia, John Benjamins.

DE MAN, P. (1986): "Conclusions: Walter Benjamin's 'The Task of the Translator”, in The Resistance to Theory, Minneapolis, University of Minnesota Press, p. 73-105.

DE Michiel, M. (1999): "Mikhail M. Bakhtin: Prolegomena to a Theory of Translation", European Journal for Semiotic Studies 11-4, p. 687-698.

EL-NAWAWY, M. and A. ISKANDAR (2003): Al-Jazeera: The Story of the Network That Is Rattling Governments and Redefining Modern Journalism, updated ed., Cambridge (MA), Westview Press.

EMERSON, C. (1983): "Translating Bakhtin: Does His Theory of Discourse Contain a Theory of Translation?", Revue de l'université d'Ottawa 53-1, p. 23-33.

FisetTe, D. (2000): « Husserl et la logique des signes », Recherches sémiotiques 20-1/2/3, p. 145-185. 
HuSSERL, E. (1970): The Crisis of European Sciences and Transcendental Phenomenology, translated by CARR, D., Evanston (IL), Northwestern University Press.

Laurendeau, P. (1997): «De la 'déformabilité' des notions en discours », Langage et Société 82, p. 27-47.

LeVenson, J. (2004): “The War on What, Exactly?”, Columbia Journalism Review, p. 9-11.

Michaud, G. (1998): «La Mémoire des mots: une lecture de l'accent dans quelques textes de Jacques Ferron », Recherches sémiotiques 18-1/2, p. 81-100.

SAID, E. (2000): "Islam as News", in BAYOumi, M. and A. RuBIN (eds.): The Edward Said Reader, New York, Vintage Books, p. 169-194.

STEINER, G. (1998): “The Hermeneutic Motion”, in After Babel: Aspects of Language and Translation, 3rd ed., New York, Oxford University Press, p. 312-435.

Wilke, J. and B. Rosenberger (1994): "Importing Foreign News: A Case Study of the German Service of the Associated Press", Journalism Quarterly 71-2, p. 421-432. 